\title{
CSR in New Normal: Realizing Good Citizenship and Corporate Social Performance for Community Development
}

\author{
Dwi Putri M.K. ${ }^{1}$, Sri Hastjarjo², Yulius Slamet ${ }^{3}$ \\ ${ }^{1,2,}, 3$ Department of Communication Studies Universitas Sebelas Maret, Surakarta, Indonesia \\ dweeputri19@student.uns.ac.id ${ }^{1}$, sri.hastjarjo@staff.uns.ac.id², yuliusslamet48@gmail.com³
}

\begin{abstract}
Abstarct. Corporate Social Responsibility (CSR) is an obligation for an organization or company in any sector including in the realm of business and its relationship with government and society. The implementation of CSR in state-owned companies especially national banks has also increased from time to time. In new normal banking, it is demanded to play an active role and contribute in national development aimed at advancing and strengthening the economy in society. Based on the Asia Money Award survey in 2017-2019, Bank Mandiri and Bank Rakyat Indonesia are the banks with the best CSR implementation in Indonesia. The purpose of this study is to determine the implementation of Corporate Social Responsibility (CSR) conducted by the two national banks in the new normal era by using the comparative method and its relation to Corporate Social Performance Theory and Corporate Citizenship. The main point is how Bank Mandiri and Bank Rakyat Indonesia (BRI) present a social responsibility and social obligation through CSR programs to stakeholders, especially the public. From this study it was concluded that after comparing Bank Mandiri and Bank Rakyat Indonesia (BRI) had similarities and differences in the implementation of CSR in new normal, although not significant.
\end{abstract}

Keywords: CSR, New Normal, Comparative, Corporate Social Performance, Corporate Citizenship

\section{Introduction}

The history of CSR began in the late 1970s and early 1980s, which was marked by increasing concern for the corporate image. Companies are required to adapt to the increasing demand for information from the public. Until 2000 Public Relations and CSR relations had a set of similarities that showed increased effectiveness and integration. Even CSR and Public Relations have the same goal to improve the quality of an organization's relationships with stakeholders [1]. External organizational communication is the main function for the survival of the organization. An organization needs to be able to manage problems, and crises to achieve its goals. All of these challenges are related to the actions of the stakeholders who are related or have an interest in the work of the organization. These stakeholders include people such as government officials, customers, service providers, and members of the surrounding environment [2]

At present Corporate Social Responsibility (CSR) is an obligation for an organization or company in any sector including in the realm of business and banking and its relationship with the government. The government also became aware of the national competitive advantage that would be won from the responsible business sector. At the same time, leading industry associations, such as the World Business Council for Sustainable Development, also suggest that countries and companies can gain a competitive advantage from corporate social 
responsibility. In many developing countries, governments and businesses understand that their respective competitive positions and capital are becoming increasingly dependent on the highest global standards [3]. There is sustainability and corporate responsibility when companies add a social dimension to their value propositions, when organizations make good social and environmental impacts it is an integral part of their overall corporate strategy. The reason behind the company's responsibility lies in the creation of values and results that are mutually beneficial to both the company's business and the community [4].

.New Normal is a way for people to live their lives differently and coexist with epidemics in life. Achmad Yurianto stated that the new normal is a new order, habits and behavior based on adaptation to civilize clean and healthy living behavior. The steps that can be done is to regularly wash hands with soap, wear a mask when going out of the house, keep a safe distance and avoid crowds. by implementing these steps the government hopes that these new habits must become a collective awareness in order to work well [5]. The team leader of the Task Force for the Acceleration of Covid-19 Handling Wiku Adisasmita said that new normal is a change in behavior to continue normal activities but with the addition of applying health protocols to prevent Covid-19 transmission and this continued until the COVID vaccine 19 found. Expert predictions when this era ends is 2021 [6].

Banking as a state-owned company in Indonesia is also experiencing rapid development, including in terms of Corporate Social Responsibility (CSR). In the last 3 years in Indonesia there were 2 (two) national banks that won the Asia Money award as Best Bank for CSR, namely Bank Mandiri and Bank Rakyat Indonesia (BRI). Asiamoney, a financial publishing company founded in 1989, has now joined the other major capital market publications of Euromoney Institutional Investor Group: Euroweek, Total Securitization and Derivatives Week, to form Global Capital [7].

Global Capital provides daily services dedicated to key market sectors such as: bank finance including closed bonds, corporate bonds, syndicated loans, equity, leverage financing, global market developments, securitization and offshore RMB. Asiamoney offers an analysis of market finance and capital investment, lending, institutional investors, and monetary decision makers of senior companies and governments with business interests in the Asia Pacific [8]

Bank Mandiri is a Bank Indonesia that received the Best Bank for CSR in Indonesia in 2017 in the Asia Money version. Bank Mandiri as one of the BUMNs that provide leading public services in Indonesia, from disaster relief to improving health and economic care standards for remote tribes, the Mandiri CSR charter is focused on developing business and financial literacy in 17,000 islands. The Mandiri Initiative is very diverse because it is spread throughout Indonesia.In southern Sumatra, Mandiri supports a training program for local Batik artisans to turn their skills into businesses. In Southeast Sulawesi, a community empowerment program for Bajo people who sailed to develop their way of life became an ecotourism. In North Lombok, Mandiri has supported what it describes as "cultural acculturation" of Hinduism, Animism and Islam into sustainable tourism programs that focus on the region's unique heritage. The Mandiri business orientation program has been attended by 36,000 young entrepreneurs from all over Indonesia who, it is hoped, will become Mandiri customers [9].

Then in 2018 and 2019 the Best Bank for CSR award was given to Bank Rakyat Indonesia (BRI). BRI promotes strategic programs, builds partnerships and starts projects to build green business models, financial inclusion and literacy that emphasize cashless transactions by developing e-channel networks to increase awareness of non-cash trading. BRI offers BRILink branchless banking services, which are operated directly by customers. At the end of 2018, BRI had 401,550 BRILink agents, or 5.7\% more than the 380,000 target, this ensured 
that BRI was able to increase financial inclusion. BRI as a state-owned company supports government programs that focus on improving the welfare of the community through loans and grants. In addition, banks provide financing for the green sector and only companies that have an environmental impact assessment document and a minimum blue rating under the Ministry of Environment and Forestry program [10].

BRI also provides funds for private companies that produce new and renewable energy, such as solar power plants and hydroelectric power plants. BRI provided a Rp2.8 trillion (\$ 197 million) loan in funding for the renewable energy sector last year. In addition, in November 2018 BRI developed a sustainable financial action plan, which includes short-term and long-term goals for the next five years. In 2019, the bank will focus on issuing sustainable bonds, providing ongoing financial training and education for employees and customers and reducing plastic consumption [11]John, Foss and Oetzel explained in general external party communication theories generally originate from two different lenses. On the one hand, several theories identify ways organizations can use communication strategically to manage reputation and maintain competitive advantage and on the other hand, theories explore how organizations can interact with stakeholders to create effective and effective relationships. sustainable in order to "do good" for the community. In his book entitled "The Theoris of Human Communication" introduces three external stakeholder communication theories: (1) situational crisis communication theory, (2) the corporate social responsibility (CSR) communication model, and (3) fully functioning theory of society.

This discussion focuses on the second theory, namely discussion on Corporate Social Responsibility (CSR). Corporate social responsibility has traditionally been the domain of business and management scholars. May, Cheney and Roper reviewed four theories about CSR. First, Shareholder Value Theory points out that CSR is important to companies only to the extent that it helps the company generate profits for its shareholders or is required by law and thus helps to avoid costs. Second, the perspective of Corporate Social Performance which believes that businesses have economic and social responsibilities. In addition to wealth created for investors, businesses have ethical responsibilities to overcome the negative consequences besides economic and legal costs. Third, Corporate Citizenship is a theoretical perspective which shows that companies are citizens of their community and thus need to pay attention to various stakeholder interests and to promote good intentions, and fourthly, Corporate Citizenship Theory includes the perspective that companies have an obligation to interact with and respond to groups support groups (stakeholders) outside the fair shareholder [12]From the four theories offered as a form of external stakeholder communication, the authors chose 2 (two) theories as the basis for the implementation of CSR carried out by the two banks, namely Corporate Social Performance and Corporate Citizenship. Based on the discussion above, why the authors are interested in examining the implementation of Corporate Social Responsibility (CSR) in the 2 (two) National Banks using a comparative study and its relation to the theory of Corporate Social Performance and Corporate Citizenship. The limitation in this study is from 2017 to July 2020, this is because the existing Corporate Social Responsibility (CSR) data is a continuation from previous years to entering the new normal period.

\section{Method}


The method used in this study is a comparative method. In recent years, comparative research in communication has gained a substantial basis. On the one hand, this can be interpreted as a sign of communication science is becoming mature as a research discipline. On the other hand, both in terms of quantity and quality, comparative communication research lags behind other disciplines, such as political science and sociology. The problem in conducting comparative empirical research is to ensure equality, namely the ability to collect data legally which can indeed be compared between various context and to avoid bias in measurements, instruments and sampling [13].

Esser and Hanitzsch conclude that comparative communication research involves a comparison between at least two macro-level cases (system, culture, market, or sub-elements) of at least one investigation object relevant to the field of communication. Comparative research differs from non-comparative work in an attempt to reach conclusions beyond a single case and explain the differences and similarities between objects of analysis and the relationship between objects and their contextual background [14].

Their article titled Comparative Research Methods further explain how the practice of comparative communication research is distinguished in five practical steps, each connected to a specific research goal. The first stage the most basic is a rounded and detailed contextual description providing knowledge about interesting topics and about factors that might be important to explain similarities and differences. The Second Stage is comparability. Exemplified here sampling, for example, after taking media samples in country A, what is equivalent in countries B, C, and D? The same applies to certain objects and concepts of analysis. Only objects that fulfill the same function (or role) can be meaningfully compared to each other.

The third stage is the determination of classification and typology, classification seeks to reduce the complexity of the world by grouping cases into different categories with characteristics that can be identified and shared. The fourth stage is an explanation for understanding the relationship between different contextual influences and their respective implications for the object of investigation. And the last stage that is considered the most extreme is the confirmed hypothesis. Because there are opportunities to predict which can be used as a solution to a problem that is prevalent in many countries. But the last stage is not used by the authors in this study because the data used are secondary data from the bank concerned, so the authors consider analyzing this discussion through 4 (four) stages. The data used in this research is secondary data obtained from books, journals to data from the official website of Bank Mandiri and Bank Rakyat Indonesia

\section{Results and Discussion}

Based on the Comparative Research Methods initiated by Esser and Vliegenhart which has been discussed in the method section, the authors try to adapt the stages of the comparative method. In the first stage the writer has described contextually rounded and detailed about the CSR of the two Banks. Next is the second stage (comparability). The author's comparative discussion is carried out by comparing the CSR program between the two banks as the table below:

Table 1. CSR Program of Bank Mandiri and Bank Rakyat Indonesia 2017-2019 


\begin{tabular}{|c|c|c|}
\hline \begin{tabular}{|l|} 
Name of \\
Bank
\end{tabular} & Bank Mandiri & Bank Rakyat Indonesia \\
\hline $\begin{array}{l}\text { Focus } \\
\text { Progra } \\
\text { ms: }\end{array}$ & $\begin{array}{l}\checkmark \text { The main focus of the Bank Mandiri } \\
\text { CSR program is to encourage } \\
\text { growth in the level of community } \\
\text { welfare. Through the } \\
\text { implementation of a sustainable } \\
\text { CSR program, } \\
\checkmark \text { Bank Mandiri wants to achieve } \\
\text { business success together with } \\
\text { improvement welfare of the } \\
\text { Indonesian people. }\end{array}$ & $\begin{array}{l}\checkmark \text { The main focus of Corporate Social } \\
\text { Responsibility (CSR), especially } \\
\text { through the implementation of the } \\
\text { Community Development } \\
\checkmark \text { Bank BRI is committed to making } \\
\text { BRI Cares an activity that has a } \\
\text { positive impact on society }\end{array}$ \\
\hline Vision & $\begin{array}{l}\text { Developing an independent } \\
\text { Indonesian community through CSR } \\
\text { Programs as inspiration to become a } \\
\text { progressive financial institution that } \\
\text { grows with Indonesia }\end{array}$ & $\begin{array}{l}\checkmark \text { To be a pioneer in corporate social } \\
\text { responsibility in empowering the } \\
\text { economy of the community of } \\
\text { Indonesia. }\end{array}$ \\
\hline Mission & $\begin{array}{l}\checkmark \text { Become a trusted primary partner for } \\
\text { the development of an independent } \\
\text { and prosperous society } \\
\checkmark \\
\text { Running CSR programs that } \\
\text { strengthen Bank Mandiri's strategy } \\
\text { with the best governance and } \\
\text { become part of Bank Mandiri's } \\
\text { comprehensive branding strategy as } \\
\text { a financial institution for all } \\
\text { stakeholders }\end{array}$ & $\begin{array}{l}\checkmark \text { Contribute to improving the } \\
\text { community's economy } \\
\checkmark \\
\text { Growing new entrepreneurs in the } \\
\text { form of group building and business } \\
\text { clusters } \\
\checkmark \\
\text { Active role in improving the quality } \\
\text { of the environment and society }\end{array}$ \\
\hline $\begin{array}{l}\text { CSR } \\
\text { Progra } \\
\text { ms }\end{array}$ & $\begin{array}{l}\text { Wirausaha Muda Mandiri (WMM) } \\
\text { CSR program of Bank Mandiri that has } \\
\text { been implemented since } 2007 \text { and aims } \\
\text { to assist the government in developing } \\
\text { entrepreneurship in Indonesia, } \\
\text { especially among the younger } \\
\text { generation. Mandiri support for } \\
\text { government programs to improve the } \\
\text { welfare of the Indonesian people and } \\
\text { form an independent Indonesian } \\
\text { community including BUMN Creative } \\
\text { Homes. Village Economic Center, } \\
\text { Coding Mum and others related } \\
\text { program. }\end{array}$ & $\begin{array}{l}\text { Indonesia Sejahtera Program } \\
\text { It is a branding of the } \\
\text { implementation of BRI's social } \\
\text { responsibility activities in the social } \\
\text { sector in the context of poverty } \\
\text { alleviation reaching Rp } 40 \text { billion } \\
\text { until the third quarter of } 2018 \text {. Some } \\
\text { of the activities are Teras BRI } \\
\text { Nusantara Program; Education and } \\
\text { training within the framework of the } \\
\text { BUMN Creative Home program, the } \\
\text { appreciation of the work disabled } \\
\text { and the Community Development } \\
\text { Fund of } 6 \text { billion }\end{array}$ \\
\hline \multirow[t]{2}{*}{$\begin{array}{l}\text { Name } \\
\text { of Bank }\end{array}$} & Bank Mandiri & Bank Rakyat Indonesia \\
\hline & $\begin{array}{l}\text { Peduli Bencana } \\
\text { Bank Mandiri's Program related to } \\
\text { response Disaster. Including Tsunami } \\
\text { Aceh, Earthquake in Banjarnegara, } \\
\text { Merapi Volcano Eruption and Others } \\
\text { disaster in Indonesia }\end{array}$ & $\begin{array}{l}\text { Indonesia peduli } \\
\text { BRI programs that are responsive in } \\
\text { order to help disasters in Indonesia } \\
\text { include: Disaster Response Post, } \\
\text { Provision of Logistics for Lombok } \\
\text { earthquake victims, Humanitarian Aid } \\
\text { for Palu Earthquake Victims and others } \\
\text { disasters in Indonesia }\end{array}$ \\
\hline
\end{tabular}




\begin{tabular}{|c|c|c|c|c|}
\hline \multirow{4}{*}{$\begin{array}{l}\text { CSR } \\
\text { Progra } \\
\text { ms }\end{array}$} & $\checkmark$ & $\begin{array}{l}\text { Peduli Pendidikan } \\
\text { Bank Mandiri CSR activities related to } \\
\text { Community Education, including: } \\
\text { Nusantara introduction program, } \\
\text { Construction of School Reading } \\
\text { Gardens in collaboration with PT Balai } \\
\text { Pustaka, Educational scholarship } \\
\text { assistance, Improvement of school } \\
\text { facilities and infrastructure etc. }\end{array}$ & $\checkmark$ & $\begin{array}{l}\text { Indonesia Cerdas } \\
\text { BRI Programs for Education include: } \\
\text { Bank BRI Scholarship Assistance to } \\
\text { students, School Equipment Packages } \\
\text { for school students building study rooms } \\
\text { etc. }\end{array}$ \\
\hline & $\checkmark$ & $\begin{array}{l}\text { Peduli Kesehatan } \\
\text { Bank Mandiri's CSR related to public } \\
\text { health include: Cleft lip surgery } \\
\text { assistance and medical devices, } \\
\text { posyandu, rehabilitation, hospital } \\
\text { renovation, support tools of RSUD, } \\
\text { free medical treatment and others }\end{array}$ & $\checkmark$ & $\begin{array}{l}\text { Indonesia Sehat } \\
\text { CSR programs in the Health Sector } \\
\text { include providing free cataract surgery } \\
\text { assistance at Sleman Hospital, providing } \\
250 \text { Ambulance units within } 5 \text { years, } \\
\text { speedboat to the government of South } \\
\text { Barito regency, ambulance to } 411 \\
\text { Pandawa Salatiga and Brajasakti } \\
\text { Payakumbuh and others }\end{array}$ \\
\hline & $\checkmark$ & $\begin{array}{l}\text { Peduli Lingkungan } \\
\text { Bank Mandiri's CSR Program related } \\
\text { to environmental concern including: } \\
\text { Program changes in the Johar Baru } \\
\text { Village, joint homecoming and cheap } \\
\text { markets in the framework of Eid and } \\
\text { others. }\end{array}$ & $\checkmark$ & $\begin{array}{l}\text { Indonesia Lestari } \\
\text { Environmental programs include: BRI } \\
\text { donates } 5000 \text { mangrove seedlings to } \\
\text { prevent abrasion from breeding coral } \\
\text { reefs and channeling } 700 \text { million funds } \\
\text { for environmental conservation }\end{array}$ \\
\hline & $\checkmark$ & $\begin{array}{l}\text { Facilities - Infrastructure } \\
\text { CSR activities related to infrastructure } \\
\text { development, public facilities and } \\
\text { infrastructure, including conducting } \\
\text { house renovations for teachers and } \\
\text { veteran, home improvement ant } \\
\text { others facilities }\end{array}$ & $\checkmark$ & $\begin{array}{l}\text { Indonesia Membangun } \\
\text { This programs are constructive } \\
\text { intended for the Development of Nature } \\
\text { Tourism in several places and the } \\
\text { construction of religious facilities }\end{array}$ \\
\hline
\end{tabular}

Source : www.mandiri.co.id and www.bri.co.id

Table 2. CSR of Bank Mandiri and Bank Rakyat Indonesia in New Normal

\begin{tabular}{|c|c|c|}
\hline $\begin{array}{l}\text { Name of } \\
\text { Bank }\end{array}$ & CSR Program & Activities \\
\hline BRI & $\begin{array}{l}\text { Corporate Social Responsibility } \\
\text { (CSR) BRI Peduli - Indonesia } \\
\text { Sehat }\end{array}$ & $\begin{array}{l}\checkmark \text { BRI has provided additional interest } \\
\text { subsidies in II (two) stages. The first } \\
\text { phase BRI distributed a KUR interest } \\
\text { subsidy stimulus of Rp } 23.97 \text { billion to } \\
211,000 \text { UMKN and in July } 2020 \text { BRI } \\
\text { distributed a non-KUR interest subsidy } \\
\text { stimulus of Rp } 10.7 \text { billion to } 47,000 \\
\text { UMKM } \\
\checkmark \quad \text { BRI provided basic assistance in the } \\
\text { form of masks, hand sanitizers and } \\
\text { Personal Protective Equipment (PPE) and } \\
\text { distributed } 200 \text { thousand masks, 5,000 } \\
\text { hand sanitizers, and } 1,000 \text { PPE to the } \\
\text { general public, government, medical } \\
\text { personnel, TNI, Polri and other } \\
\text { institutions engaged in the field of }\end{array}$ \\
\hline
\end{tabular}




\begin{tabular}{|c|c|c|}
\hline & & $\begin{array}{l}\text { handling of Covid-19. BRI Assistance in } \\
\text { spraying disinfectants aimed at public } \\
\text { facilities and other public facilities in } \\
\text { three major cities of Jakarta, Surabaya } \\
\text { and Medan. } \\
\checkmark \quad \text { BRI cooperates with the State Bank } \\
\text { Association (HIMBARA) and Kimia } \\
\text { Farma to conduct socialization inviting } \\
\text { people to maintain environmental health } \\
\text { and hygiene }\end{array}$ \\
\hline $\begin{array}{l}\text { Bank } \\
\text { Mandiri }\end{array}$ & $\begin{array}{l}\text { CSR of Bank Mandiri - Mandiri } \\
\text { untuk negeri }\end{array}$ & $\begin{array}{l}\checkmark \text { Bank Mandiri through PPNI } \\
\text { Provides financial assistance to Nurses } \\
\text { Who Died in the Covid-19 Pandemic } \\
\checkmark \quad \text { Bank Mandiri generated a micro } \\
\text { economy involving small stalls and food } \\
\text { agents to prepare assistance in the form } \\
\text { of } 120 \text { thousand food and food packages } \\
\text { with a total value of Rp } 6 \text { billion. The } \\
\text { packages were then distributed to } \\
\text { communities whose economies were } \\
\text { affected by the Covid-19 pandemic. } \\
\checkmark \quad \text { Bank Mandiri accelerated the } \\
\text { Restructuring of } 404,000 \text { debtors with } \\
\text { funds of Rp } 99 \text { trillion, Rp } 51.6 \text { trillion } \\
\text { were wholesale banking, corporate and } \\
\text { commercial banking segments and } \\
\text { Rp.47.3 trillion came from the retail, } \\
\text { MSME, KPR and KSM segments }\end{array}$ \\
\hline
\end{tabular}

Source : www.mandiri.co.id and www.bri.co.id

Based on the CSR programs that have been carried out by the two banks, the next step is to determine the typology crucially. There are three things that can be summarized based on the CSR program initiated by the two banks. First is the main focus, Bank Mandiri has a main focus on the welfare of society while BRI's main focus is to have a positive impact on people who are broadly similar. By raising the issue of the community indirectly, BRI and Bank Mandiri have provided information that the CSR programs undertaken by both are carried out seriously and contribute to the community, even in the new normal era the two banks carried out various activities that supported the economic strength of the community as business actors including KUR subsidies for UMKM, improve microeconomics, and accelerate restructuring. these things are called Ralph and his colleagues as the main factors of CSR [15]. This main focus is also aligned with the vision and mission of BRI and Bank Mandiri, which carries out the CSR program in order to grow, strengthen and empower the Indonesian people financially so that the community's economy increases.

The second are many similarities both in the type of program initiated and the objectives to be achieved. Although most are different in language, the meaning of each activity is the same. Based on table 1 six of the CSR programs of Bank Mandiri and BRI there are 5 programs that are almost similar. Observe the program Peduli Bencana and Indonesia Peduli that both CSR program that aims to assist disaster in several regions in Indonesia, the program Peduli Pendidikan and Indonesia Cerdas aimed to improve the quality of education in Indonesia, Peduli Lingkungan program and Indonesia Peduli that focuses on sustainability environment, Peduli Kesehatan Program and Indonesia Sehat program which focuses on 
public health and finally Sarana - Prasarana Program and Indonesia Membangun program aimed at building public facilities such as roads, bridges, places of worship, schools and other facilities.

The third is Bank Mandiri and BRI's responsive attitudes and actions in the face of new norms in various CSR programs. Forms of corporate social responsibility to the community can include various aspects as giving charity to the community, giving in the form of goods from the company's products and services that need it, or using facilities or managerial expertise that helps those in need, and more [16]. Bank Mandiri and BRI have carried out these activities significantly, especially those related to the coronavirus pandemic. As we know health is a very important and crucial issue in the new normal era and this has been applied by both banks in a sustainable program. Before the pandemic hit Indonesia, the two banks had CSR Program such as Indonesia Sehat dan Peduli Kesehatan, both of which aimed to encourage the creation of health in the community. In the new normal era CSR still carries the same program but with different packaging. Public health assistance is manifested in different forms such as compensation for nurses who died during the pandemic, basic assistance in the form of masks, hand sanitizers and personal protective equipment (PPE), disinfectant spraying, provision of portable washbasins and other supporting activities. In this section the bank as a financial institution can respond to the wishes of the community well through CSR programs run by the company which is referred to as Corporate Social Performance and Corporate citizenship.

Based on the three issues above can be formulated in the final stage that Bank Mandiri and Bank Rakyat Indonesia (BRI) have similarities and differences in the implementation of CSR, although not significantly. This can be seen in the two CSR programs used by the two banks to communicate their CSR programs with stakeholders, including CSR reports, social media, advertisements, and direct dialogue. The CSR report itself is posted on the official website of each bank which is available and can be accessed anytime by all groups. The role of CSR is a reflection of the existence of a company in developing philanthropic projects to the community. Involving the community in all CSR programs creates communication patterns between the community and the company. There is almost no CSR program that does not come into contact with the community because if the community does not know or know the CSR program. Ralph Tench and his colleagues named it missing information.

\section{Conclusions}

Bank Mandiri and Bank Rakyat Indonesia (BRI) have presented a form of social responsibility and social obligation to the community in the new normal era, this is manifested in a variety of programs that are carried out. The program is not only useful for creating a positive image for the company but also as an effort to create strong and effective communication between the company and stakeholders in the present and the future.

\section{References}

[1] Cythia E. Clark, "Differences Between Public Relations and Corporate Social Responsibility : An Analysis," Public Relations Review, pp. 363,366, 2000. 
[2] Karen A.Foss Stephen W. Littlejohn and John G Oetzel, Theories of Human Communication, eleventh Edition ed. United States of America: Waveland Press, Inc., 2017.

[3] Paul Hohnen, Corporate Social Responsibilty: An Implementation Guide for Business. Canada: Internasional Institute for Sustainable Development, 2007.

[4] Mark Anthony (Ed) Camilleri, "The Corporate Sustainability and Responsibility Proposition: A Review and Appraisal.," in CSR 2.0 and the New Era of Corporate Citizenship.: IGI Global., 2016.

[5] Kementerian Kesehatan. (2020, May) www.kemkes.go.id. [Online]. https://www.kemkes.go.id/article/view/20052900001/vaksin-covid-19-belum-ditemukanpemerintah-siapkan-skenario-new-normal.html

[6] Dandy Bayu Bramasta. (2020, May) www. kompas.com. [Online]. https://www.kompas.com/tren/read/2020/05/16/164600865/sering-disebut-sebut-apa-itu-newnormal-?page $=$ all.

[7] Asiamoney. (2019, September) euromoney.com. [Online]. www.euromoney.com

[8] wikipedia. (2020, April) https://en.wikipedia.org/. [Online]. https://en.wikipedia.org/wiki/Asiamoney

[9] Bank Mandiri. (2019, December) mandiri.co.id. [Online]. www.mandiri.co.id

[10] okezone.com. (2019, October) www.okezone.com. [Online]. https://economy.okezone.com/read/2019/10/04/320/2113122/lagi-bri-dinobatkan-asiamoneysebagai-best-bank-for-csr

[11] Bank Rakyat Indonesia, "Laporan Keberlanjutan 2019," PT. Bank Rakyat Indonesia Persero (Tbk), Jakarta, Anual Report BRI-SR-2019, 2019.

[12] George Cheney Steve Kent May and Juliet Roper, The Debate Over Corporate Social Responsibility. England: Oxford University Press, 2007.

[13] Rens Vliegenthart Frank Esser, The Comparative Research Methods. The International Encylopedia of Communication Research Methods.: John Wiley \& Sons, Inc., 2017.

[14] T Hanitzsch Frank Esser, On The Why and How Comparative Inquiry In Communication Studies, HandBook of Comparative Communication Research. London: Routledge, 2012.

[15] Liz Yeomans Ralph Tench, Exploring Public Relation. United Kngdom: Pearson Education Limited, 2017.

[16] Shaike Marom (Corresponding Author) and Robert N Lussier, "Corporate Social Responsibility during the coronavirus pandemic : An Interim Overview," Macrothink Institute, vol. 10 No.2, no. Bussines and Economic Research, p. 255, 2020. 